\section{Time of Aminoethoxyvinylglycine Application Influences Preharvest Drop and Fruit Quality of 'McIntosh' Apples}

\author{
Duane W. Greene \\ University of Massachusetts, Plant, Soil, and Insect Science, Bowditch Hall, \\ Amherst, MA 01003 \\ Additional index words. AVG, ReTain, fruit abscission, NAA, naphthaleneacetic acid, Malus \\ $\times$ domestica
}

\begin{abstract}
AVG was applied as the ReTain formulation over three harvest seasons to determine the influence of time of application on drop control efficacy and its influence on fruit maturity of 'McIntosh' apples. Effective drop control was achieved through the commercial harvest season with application of AVG made from 1 to 6 weeks before the anticipated start of harvest for untreated fruit. Drop control extended beyond the normal harvest period when application was made either 2 weeks or 1 week before anticipated harvest. Application made between 6 and 4 weeks before anticipated harvest generally delayed parameters associated with ripening, such as softening, degradation of starch, and development of red color, more than applications made on later dates. While AVG consistently and effectively retarded abscission, the length of time it controlled drop varied from year to year, even when used on similar trees in the same block. Once applied, it required 10 to 14 days before AVG started to retard fruit abscission. AVG controlled drop linearly with increasing concentration. AVG was a superior drop control compound than NAA. Chemical names used: aminoethoxyvinylglycine (AVG), naphthaleneacetic acid (NAA).
\end{abstract}

Aminoethoxyvinylglycine (AVG) is a naturally occurring compound that was found in the early 1970 s to inhibit ethylene biosynthesis (Boller et al., 1979). Early in its development it was recognized that AVG had the capability to retard preharvest drop of apples (Bangerth, 1978). However, it was an expensive compound to produce, so commercial development was suspended. Following the withdrawal of registration of daminozide for drop control on apples in 1989, Abbott Laboratories resumed development of AVG (Clarke et al., 1996).

Early work with AVG was generally conducted using dilute hand gun application (Byers, 1997a, 1997b; Greene, 2002b; Greene and Schupp, 2004; Schupp and Greene, 2004). In experiments where a commercial sprayer was used for AVG application, a recommended surfactant was not included (Byers, 1997a, 1997b). More recently where an appropriate surfactant was included, tree row volume applications were made using speed-sprayersimulated hand gun applications (Stover et al., 2003; Wargo et al., 2004). Consequently, the most recently published data on AVG was not generated following AVG label recommendations and those that are currently used by orchardists.

Previous reports have shown that the time of AVG application can influence preharvest drop and fruit quality (Byers, 1997b; Greene and Schupp, 2004). However, none of this information was generated using the current AVG formulation, the correct recommended surfactants, and application with a commercial airblast sprayer. Therefore, this investigation was undertaken to determine the effect

Received for publication 26 July 2005. Accepted for publication $29 \mathrm{Aug} .2005$. of AVG application when applied at several timings before the normal anticipated time of ripening.

\section{Materials and Methods}

Plant material. All trees used in this investigation were mature 'Marshall McIntosh'/ Mark that were growing at the University of Massachusetts Horticultural Research Center, Belchertown, Mass. Normal cultural and pest control practices were used.

Experiment 1: Timing and concentration, 1996. In a block of Marshall 'McIntosh'60 pairs of trees were selected that were separated by at least one buffer tree. One tree in each pair was designated to be the sample tree, from which all harvest samples were collected. No fruit were harvested from the second tree, and this served to follow the progression of fruit drop. Tree pairs were placed into six blocks (replications) based upon proximity in the orchard and crop load. On 15 Aug., 4 weeks before anticipated harvest, one pair of trees in each replication was sprayed with $90 \mathrm{mg} \cdot \mathrm{L}^{-1}$ aminoethoxyvinylglycine (as the ReTain formulation,

Abbott Laboratories, North Chicago, Ill.) in $0.1 \%$ Silwet L-77 silicone surfactant, a proprietary silicone polyether copolymer, (Loveland Industries, Loveland, Colo.). Application was made with a commercial airblast sprayer at the tree row volume (TRV) of $1169 \mathrm{~L} \cdot \mathrm{ha}^{-1}$. On the same day another pair of trees in each replication similarly received an AVG application of $45 \mathrm{mg} \cdot \mathrm{L}^{-1}$. Second and third applications of AVG at 45 and $90 \mathrm{mg} \cdot \mathrm{L}^{-1}$ were similarly made on different pairs of trees in each replication on 29 Aug. and 5 Sept., 2 weeks and 1 week before anticipated harvest, respectively. Three pairs of trees in each replication received no spray and served as AVG controls for the three times of AVG application. One pair of trees in each block was sprayed on 5 Sept. with 10 $\mathrm{mg} \cdot \mathrm{L}^{-1} \mathrm{NAA}$ with an airblast sprayer delivering a TRV of $1168 \mathrm{~L} \cdot \mathrm{ha}^{-1}$.

Twenty fruit were harvested randomly from the perimeter of each sample tree on $12 \mathrm{Sept}$. and then weighed. Percent of the surface with red color was estimated to the nearest $10 \%$ as well as determining if the red color was intense enough to meet U.S. Extra Fancy red color standards. A subsample of 10 fruit, representative of the sample, was selected and flesh firmness determined on two sides of each fruit using a hand-held Effegi penetrometer (McCormick Fruit Co., Yakima, Wash.). Soluble solids concentration (SSC) were determined on a composite sample of juice collected while assessing flesh firmness, using a hand-held refractometer (Fisher, Pittsburgh, Pa.). Fruit from the firmness test were cut in half at the equator, dipped in a starch-iodine solution, and the starch pattern was then rated using a generic starch chart (Blanpied and Silsby, 2002). Twenty fruit were similarly harvested and evaluated from sample trees on 19 Sept., 26 Sept., and 3 Oct. On 29 Aug., all fruit were removed under drop trees and discarded. Twice weekly, all fruit under the drop trees were removed and counted. On 25 Oct., all fruit remaining on the drop trees were harvested and counted and the weekly cumulative drop calculated.

Experiment 2: Time of application, 1997. Forty-two pairs of mature 'Marshall McIntosh'/ Mark were selected that were separated by at least one buffer tree. One tree in each pair was designated as a sample tree and the second as a drop tree, as previously described. Pairs were grouped into six blocks of seven pairs of trees each, based upon crop load and location within the orchard. One pair of trees in each block was sprayed 15 Aug. with $90 \mathrm{mg} \cdot \mathrm{L}^{-1}$ AVG as the ReTain formulation in $0.1 \%$ Silwet L-77 at the TRV of $1169 \mathrm{~L} \cdot \mathrm{ha}^{-1}$. Two other pairs of trees in each block were sprayed with the same AVG spray on 29 Aug. and 5 Sept. Three pairs of trees in each block were unsprayed and served as controls for the three times of application. NAA at $10 \mathrm{mg} \cdot \mathrm{L}^{-1}$ was applied at TRV to one pair of trees in each block on 5 Sept. Twenty fruit were harvested from each sample tree on 11, 18, and 25 Sept. and 2 Oct. and evaluated as described in Expt. 1. All fruit were picked up under drop trees on 5 Sept. and discarded. Fruit were then picked up under drop trees two times weekly until 27 Oct. when the fruit remaining on the trees were harvested and cumulative drop calculated.

Experiment 3: Time of application, 1998. Sixty pairs of mature 'Marshall McIntosh'/ Mark separated by a buffer tree were selected. Trees in each pair were designated as either a drop or a sample tree as previously described. Pairs were grouped into six blocks (replications) of six pairs of trees each based on crop load and location in the orchard. One pair of trees in each block was sprayed using a commercial airblast sprayer with $105 \mathrm{mg} \cdot \mathrm{L}^{-1} \mathrm{AVG}$ in $0.1 \%$ Silwet at the TRV of $1169 \mathrm{~L} \cdot \mathrm{ha}^{-1}$ on $3,10,18,24$, and 31 Aug. One pair of trees 
within each block was not treated and served as a control. Atwenty apple sample was harvested from each sample tree on 10, 17, and 24 Sept. and 1 Oct. and evaluated as described in Expt. 1. All fruit were removed under drop trees on 1 Sept. and discarded. Fruit were picked up under drop trees two times weekly until 22 Oct., when the fruit remaining on the trees were harvested and cumulative drop calculated.

Statistical analysis. Statistical analysis was done twice using analysis of variance. The first was analysis of regression using only AVG. The second analysis used all treatments, where treatment means were separated by orthogonal polynomial comparison.

\section{Results}

Experiment 1: Time and concentration, 1996. There was a linear reduction of preharvest drop attributed to AVG (Table 1). It was not until 18 Oct. that there was significance in response attributed to time of application and it occurred only on that date (Table 1). NAA did retard drop relative to the control early in the season, but drop control with AVG was superior and lasted longer than NAA. AVG had no influence on fruit weight (Table 2). However, it did reduce red color development and the number of fruit that could be classified as US Extra Fancy fruit in a linear fashion. There was an AVG $\times$ harvest date interaction. AVG had no effect on red color development at the first harvest time on 12 Sept., but on subsequent harvest dates it reduced red color development (data not shown). No treatment influenced SSC. AVG reduced the starch rating in the fruit linearly and the time of application influenced the response. The later AVG was applied the less effect that it had on retarding starch degradation. AVG fruit were firmer at harvest, with the early application date (4 weeks before harvest) having greater flesh firmness than when application was made wither two or one week before anticipated initial harvest. There was also an $\mathrm{AVG} \times$ harvest date interaction. Delayed softening attributed to AVG was not as great at the early harvests as it was on later harvest dates (data not shown).
Experiment 2: Time of application, 1997. AVG retarded preharvest drop relative to the untreated control for the duration of the experiment (Table 3). However, the time of application influenced the response. Until 9 Oct., applications made at 4, 2, or 1 week before anticipated harvest of untreated trees responded similarly. From 9 Oct. to the termination of the experiment, applications made 1 and 2 weeks before anticipated harvest controlled drop similarly and better than when the same amount of AVG was applied at 4 weeks before anticipated initial harvest of untreated trees. At no time did NAA retard preharvest drop.

Fruit weight at harvest was not influenced by any treatment (Table 4). AVG reduced red color development, but the reduction and the intensity of the red blush was not reduced sufficiently to affect the percent fruit classified as U.S. Extra Fancy fruit. AVG-treated fruit were firmer. There was an $\mathrm{AVG} \times$ harvest interaction. AVG did not influence flesh firmness at the first harvest, but it slowed the loss of firmness so that at subsequent harvests AVG-treated fruit were firmer (data not shown). AVG retarded the loss of starch from fruit resulting in a lower starch rating. The time it was applied also influence starch rating. Early application four weeks before anticipated harvest resulted in a lower starch rating, the intermediated time of application resulted in less retardation, while the latest application made 1 week before anticipated harvest, resulted in no retardation in starch rating.

Experiment 3: Time of application, 1998. AVG retarded preharvest drop, but the time of application influenced the response (Table 5). Early preharvest drop during the first two weeks of September appeared to be controlled by applications made between 3 and 24 Aug., but not by the one made on 31 Aug. Therefore, it appears that between 10 and $14 \mathrm{~d}$ is required following AVG application for the effect on retarding preharvest drop to take effect. Time of application also influenced drop control starting on 1 Oct. and on subsequent dates. Application on earlier dates resulted in less effective drop control than when the application was made 2 weeks before anticipated start of harvest.

AVG did not influence fruit weight although there was an $\mathrm{AVG} \times$ harvest date interaction (Table 6). AVG-treated fruit were smaller on the first harvest but on subsequent harvests from the same trees there was no effect (data not shown). AVG treatments, when considered as a whole, did not influence red color development or the percent U.S. Extra Fancy fruit, but there was a linear reduction in red color development and U.S. Extra Fancy fruit, with the early application causing reduced red color and subsequent applications causing progressively less reduction (data not shown). No treatment influenced fruit soluble solids. AVG-treated fruit were firmer and had lower starch rating, and the time of application had no influence.

\section{Discussion}

The discovery, development, registration, and ultimate commercial use of a plant growth regulator goes through an evolutionary process (Greene, 2002a). For AVG the pathway to product registration spanned 3 decades. The precipitating event that ultimately resulted in the registration of AVG for preharvest drop control and harvest management of apples was the loss of registration of daminozide in 1989 Schupp and Greene, 2004). Early development of the use of AVG on apples was previously described (Greene, 2000). Further development which provided information useful in writing a label for the registration is published in several papers (Byers, 1997a; Clarke et al., 1996; Greene, 2000; Greene and Schupp, 2004; Schupp and Greene, 2004; Shafer et al., 1997). The purpose of this paper is to describe the final stage in product development where the effects of concentration and time of application of $\mathrm{AVG}$ as the ReTain formulation are used under commercial conditions.

Drop control response to AVG application where these data are provided is linear with increasing concentration over a wide range of concentrations (Greene, 2002; Greene and Schupp, 2004; Schupp and Greene, 2004). The

Table 1. Effect of AVG concentration and time of application and NAA on cumulative drop of 'Marshall McIntosh'/Mark apples; 1996 , Expt. 1.

\begin{tabular}{|c|c|c|c|c|c|c|c|c|c|c|}
\hline \multirow{2}{*}{$\begin{array}{l}\text { Treatment }^{z} \\
\left(\mathrm{mg} \cdot \mathrm{L}^{-1}\right)\end{array}$} & \multirow{2}{*}{$\begin{array}{l}\text { Weeks before } \\
\text { anticipated } \\
\text { harvest }\end{array}$} & \multirow{2}{*}{$\begin{array}{c}\text { Date } \\
\text { applied }\end{array}$} & \multicolumn{8}{|c|}{ Cumulative drop ( $\%$ of total on tree) } \\
\hline & & & 5 Sept. & 12 Sept. & 19 Sept. & 26 Sept. & 3 Oct. & 11 Oct. & 18 Oct. & 25 Oct. \\
\hline AVG 0 (control) & 4 & 15 Aug. & 1.0 & 3.6 & 12.6 & 37.6 & 69.6 & 89.1 & 97.1 & 99.9 \\
\hline AVG 45 & 4 & 15 Aug. & 0.2 & 1.8 & 5.2 & 13.0 & 33.3 & 48.0 & 83.4 & 96.0 \\
\hline AVG 90 & 4 & 15 Aug. & 0.6 & 1.2 & 3.2 & 5.1 & 11.4 & 18.6 & 48.3 & 78.6 \\
\hline AVG 0 (control) & 2 & 29 Aug. & 0.5 & 3.2 & 12.5 & 33.2 & 68.3 & 85.3 & 96.2 & 99.7 \\
\hline AVG 45 & 2 & 29 Aug. & 1.1 & 2.9 & 7.2 & 15.3 & 32.6 & 49.6 & 79.6 & 95.9 \\
\hline AVG 90 & 2 & 29 Aug. & 0.6 & 1.6 & 4.7 & 9.4 & 22.5 & 34.0 & 60.3 & 81.9 \\
\hline AVG 0 (control) & 1 & 5 Sept. & 0.9 & 4.4 & 12.4 & 32.0 & 68.5 & 89.4 & 95.9 & 99.5 \\
\hline AVG 45 & 1 & 5 Sept. & 1.0 & 4.2 & 8.9 & 15.8 & 30.4 & 47.6 & 77.3 & 95.8 \\
\hline AVG 90 & 1 & 5 Sept. & 0.8 & 2.1 & 3.9 & 5.8 & 12.1 & 19.2 & 37.0 & 68.9 \\
\hline NAA 10 & --- & -- & 0.9 & 3.7 & 7.3 & 21.1 & 52.5 & 69.4 & 82.0 & 95.8 \\
\hline \multicolumn{11}{|l|}{ Significance } \\
\hline \multicolumn{3}{|c|}{ AVG concentration } & NS & $\mathrm{L}^{* * *}$ & $\mathrm{~L}^{* * *}$ & $\mathrm{~L}^{* *}$ & $\mathrm{~L}^{* * * *}$ & $\mathrm{~L}^{* * * *}$ & $\mathrm{Q}^{* *}$ & $\mathrm{Q}^{* * *}$ \\
\hline \multicolumn{3}{|c|}{ AVG time of application } & NS & NS & NS & NS & NS & NS & $*$ & NS \\
\hline \multicolumn{3}{|c|}{ AVG concentration $\times$ time } & NS & NS & NS & NS & NS & NS & $*$ & NS \\
\hline \multicolumn{3}{|c|}{ Control vs. NAA } & NS & NS & $* *$ & $* *$ & $* *$ & $* *$ & $* *$ & NS \\
\hline \multicolumn{3}{|c|}{ AVG vs. NAA } & NS & NS & NS & $*$ & $* * *$ & $* * *$ & $* * *$ & $* * *$ \\
\hline
\end{tabular}

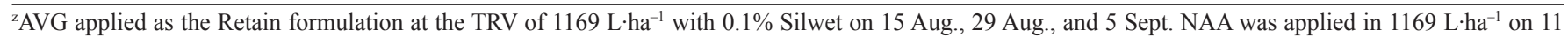
Sept.

NS,********Nonsignificant at or significant at $P=0.05,0.01$, or 0.001 , respectively; $\mathrm{L}=$ linear and $\mathrm{Q}=$ quadratic response. 
ReTain label restricts maximum active ingredient application to $124 \mathrm{~g} \cdot \mathrm{ha}^{-1}$ regardless of tree size or tree row volume (TRV). The concentrations of 45 and $90 \mathrm{mg} \cdot \mathrm{L}^{-1}$ AVG selected for use and reported in Table 1 is a representative and realistic TRV dilute active ingredient applications of $124 \mathrm{~g} \cdot \mathrm{ha}^{-1}$ that might be used in the northeastern U.S. on commercial blocks of 'McIntosh' on M.26 and M.9 rootstocks, respectively. If the same active ingredient were to be applied to larger trees with a greater TRV, one might reasonably expect to have reduced drop control on these larger trees.

AVG may be used commercially as a drop control agent for two distinctly different purposes and these may influence both the concentration used and the type of trees it is used on. First, 'McIntosh', is the dominant cultivar grown in New England and northern New York state and it effectively ripens over 2 to 2.5 weeks. It is a logistical challenge to harvest a large portion of the crop in such a compressed time period. Use of AVG at perhaps more than one rate per ha to delay ripening and retard preharvest drop provides orchardists with the flexibility to manage harvest so that high quality fruit may be harvested with minimal loss due to preharvest drop. Secondly, a significant number of orchardists sell their crop directly to the public through pick-your-own. It is very advantageous to have the extremely familiar and popular cultivar 'McIntosh' available not only during the traditional harvest season for 'McIntosh' but well into October, a time when apple sales peak in New England. In this circumstance the maximum allowed amount of ReTain should be applied and its applications should be delayed until 1 to 2 weeks before anticipated harvest of untreated trees for the greatest preharvest drop control late into the season. Preharvest interval is $21 \mathrm{~d}$ following application, so blocks treated in this way should be designated for later harvest.

Application of AVG has been done as much as 8 weeks in advance of the anticipate harvest date, but this is too early to be effective on drop control at harvest (Schupp and Greene, 2004). In this investigation applications were made during three different growing seasons, on the same block of trees, between 1 and 6 weeks before anticipated harvest with a different response being documented in each of the years. In 1996 the time of application between 1 and 4 weeks before harvest was only significant at one time during the evaluation to 25 Oct., whereas in 1997 differences occurred starting in the second week in October and in 1998 the differences in drop control became significant on 1 Oct. Therefore, the time after application that AVG loses its effectiveness as a drop control compound is as much related to the conditions occurring during the year applied as it is to the time of application in a specific year.

The time of application of AVG had a small effect on fruit quality and maturity at harvest. Early application of AVG generally delayed ripening more since fruit were firmer in 1996, starch degradation was delayed in 1996 and 1997, and red color was reduced in 1998. The most likely explanation is that early application of AVG reduced fruit ethylene levels sooner in the maturation process, which in turn delayed the ripening process.

Previous reports have not established a time

Table 2. Effect of concentration and time of AVG application on fruit quality at harvest on 'Marshall McIntosh'/M.26 apples; 1996, Expt. 1. Mean of harvests on 12 Sept., 19 Sept., 26 Sept., and 3 Oct.

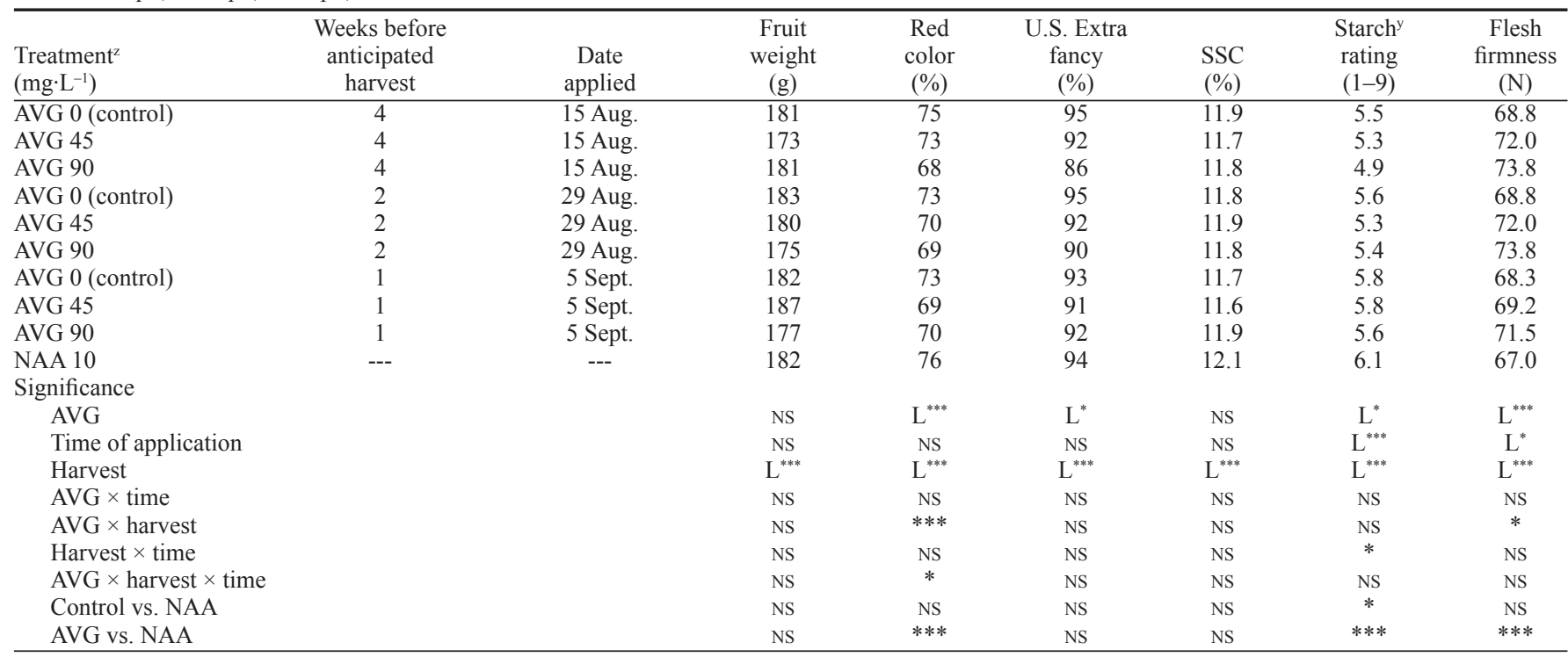

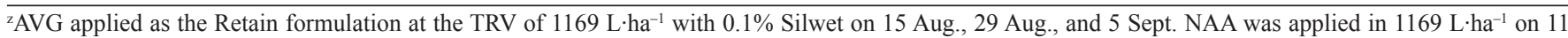
Sept.

y $1-3=$ immature, $4-6=$ mature, and $7-9=$ over-mature.

NS, ,*******Nonsignificant at or significant at $P=0.05,0.01$, or 0.001 , respectively; $\mathrm{L}=$ linear and $\mathrm{Q}=$ quadratic response.

Table 3. Effect of time of AVG application and NAA on preharvest drop of 'Marshall McIntosh' apples; 1997, Expt. 2.

\begin{tabular}{|c|c|c|c|c|c|c|c|c|c|c|c|c|c|c|c|c|}
\hline \multirow{2}{*}{$\begin{array}{l}\text { Treatment }^{2} \\
\left(\mathrm{mg} \cdot \mathrm{L}^{-1}\right)\end{array}$} & \multirow{2}{*}{$\begin{array}{c}\text { Weeks before } \\
\text { anticipated } \\
\text { harvest }\end{array}$} & \multirow{2}{*}{$\begin{array}{c}\text { Date } \\
\text { applied }\end{array}$} & \multicolumn{14}{|c|}{ Cumulative drop (\%) } \\
\hline & & & 11 Sept. & 15 Sept. & 18 Sept. & 22 Sept. & 25 Sept. & 29 Sept. & 2 Oct. & 6 Oct. & 9 Oct. & 14 Oct. & 16 Oct. & 20 Oct. & 23 Oct. & 27 Oct. \\
\hline$\overline{\text { Control }}$ & 4 & 15 Aug. & 4 & 11 & 19 & 31 & 37 & 49 & 58 & 75 & 88 & 96 & 98 & 98 & 100 & 100 \\
\hline AVG 90 & 4 & 15 Aug. & 2 & 3 & 5 & 7 & 9 & 12 & 16 & 23 & 38 & 60 & 68 & 81 & 90 & 92 \\
\hline Control & 2 & 29 Aug. & 4 & 13 & 24 & 36 & 43 & 57 & 65 & 78 & 89 & 96 & 98 & 99 & 100 & 100 \\
\hline AVG 90 & 2 & 29 Aug. & 1 & 2 & 2 & 3 & 4 & 4 & 6 & 8 & 13 & 19 & 24 & 34 & 45 & 52 \\
\hline Control & 1 & 5 Sept. & 4 & 11 & 17 & 28 & 34 & 46 & 58 & 76 & 90 & 97 & 98 & 99 & 100 & 100 \\
\hline AVG 90 & 1 & 5 Sept. & 3 & 4 & 6 & 6 & 7 & 8 & 9 & 11 & 13 & 20 & 23 & 34 & 44 & 51 \\
\hline NAA 10 & --- & 5 Sept. & 3 & 7 & 14 & 27 & 37 & 53 & 63 & 77 & 88 & 96 & 97 & 98 & 99 & 100 \\
\hline \multicolumn{17}{|l|}{ Significance } \\
\hline $\mathrm{AVG}$ & & & $* *$ & $* * *$ & $* * *$ & $* * *$ & $* * *$ & $* * *$ & $* * *$ & $* * *$ & $* * *$ & $* * *$ & $* * *$ & $* * *$ & $* * *$ & $* * *$ \\
\hline \multicolumn{3}{|c|}{ Time of application $(\mathrm{T})$} & NS & NS & NS & NS & NS & NS & NS & NS & $\mathrm{L}^{* *}$ & $\mathrm{~L}^{* * *} \mathrm{Q}^{* * *}$ & $\mathrm{~L}^{* * * *} \mathrm{Q}^{* *}$ & $\mathrm{~L}^{* * * *} \mathrm{Q}^{* * *}$ & $\mathrm{~L}^{* * *} \mathrm{Q}^{* * *}$ & $\mathrm{~L}^{* * *} \mathrm{Q}^{* * *}$ \\
\hline $\mathrm{AVG} \times \mathrm{T}$ & NS & & NS & NS & NS & NS & NS & NS & NS & $* *$ & $* * *$ & $* * *$ & $* * *$ & $* * *$ & $* * *$ & \\
\hline \multicolumn{3}{|c|}{ NAA vs. AVG } & NS & NS & $*$ & $* * *$ & $* * *$ & $* * *$ & $* * *$ & $* * *$ & $* * *$ & $* * *$ & $* * *$ & $* * *$ & $* * *$ & $* * *$ \\
\hline \multicolumn{3}{|c|}{ NAA vs. control } & NS & NS & NS & NS & NS & NS & NS & NS & NS & NS & NS & NS & NS & NS \\
\hline
\end{tabular}

${ }^{2} \mathrm{AVG}$ applied as the Retain formulation at the TRV of $1169 \mathrm{~L} \cdot \mathrm{ha}^{-1}$ with $0.1 \%$ Silwet.

${ }_{\text {NS }, * * * * * * * *}$ Nonsignificant at or significant at $P=0.05,0.01$, or 0.001 , respectively; $\mathrm{L}=$ linear and $\mathrm{Q}=$ quadratic response. 
between AVG application and when it starts to retard preharvest drop control becomes effective. This is often times difficult to establish because preharvest drop frequently does not start until later in the season. In this investigation application of AVG 1 week before anticipated harvest in 1996 and 1997 was adequate was adequate for early drop control since significant drop did not begin until later in the season. In 1998 there was an AVG $\times$ time of application interaction. Drop started earlier in 1998 and
AVG was not effective at controlling drop as earlier applications until between 10 and 14 Sept. Therefore, we can conclude from this that between 10 to $14 \mathrm{~d}$ is required from the time of AVG application until effective drop control is in place.

Commercially AVG is used for drop control and to delay ripening about 4 weeks before the anticipated start of normal harvest of untreated trees. Results from this investigation suggest that the window of opportunity for the ap- plication of AVG as the ReTain formulation is quite wide. Clearly, applications made 2 weeks before harvest in all 3 years were as effective as those made at 4 weeks before harvest. Therefore, orchardist should select a good day to apply AVG during the application window to assure appropriate weather for good spray coverage.

NAA was used as a drop control check in 2 of the 3 years. In these years NAA was a less effective control compound and in both years

Table 4. Effect of time of AVG application and NAA on fruit weight, fruit quality parameters at harvest, and ripening of 'Marshall McIntosh' apples; 1997, Expt. 2. Mean of harvests on 11 Sept., 18 Sept., 25 Sept., and 2 Oct.

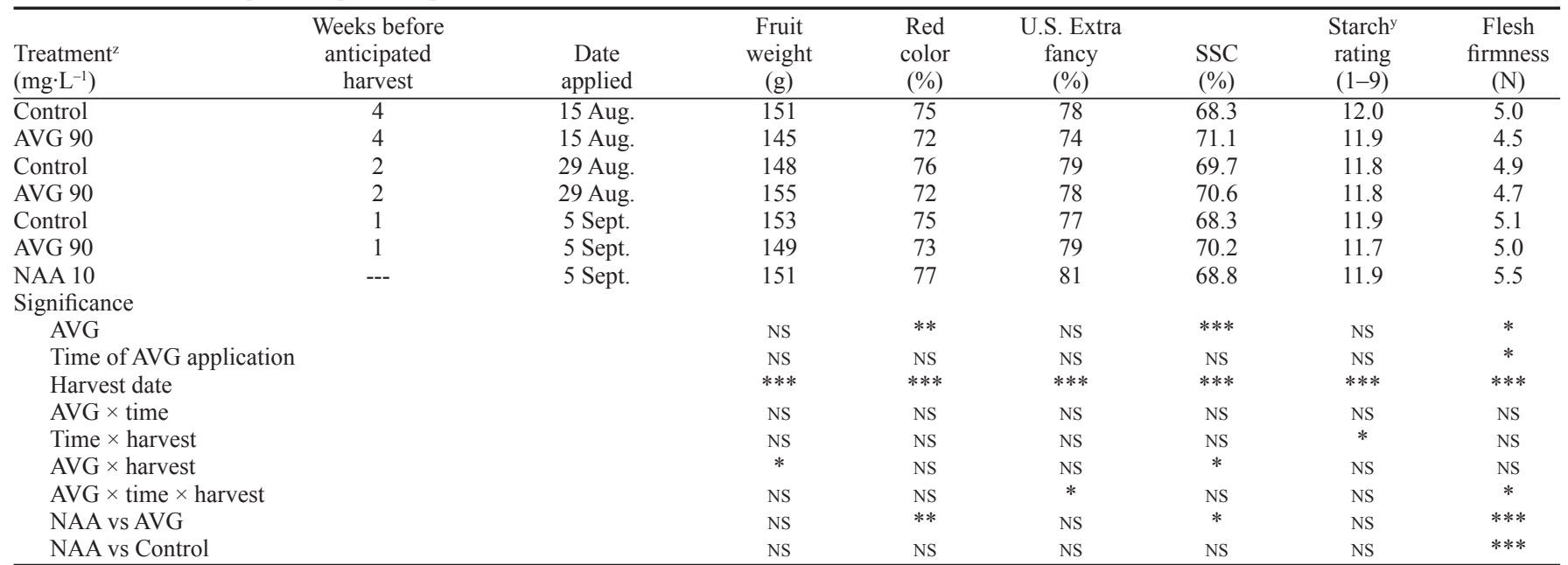

${ }^{2} \mathrm{AVG}$ was applied as the Retain formulation at the TRV of $1169 \mathrm{~L} \cdot \mathrm{ha}^{-1}$ with $0.1 \%$ Silwet.

${ }^{\mathrm{y}} 1-3=$ immature; $4-6=$ mature; and 7-8 = over-mature.

NS,*******Nonsignificant at or significant at $P=0.05,0.01$, or 0.001 , respectively; $\mathrm{L}=$ linear and $\mathrm{Q}=$ quadratic response.

Table 5. Effect of time of AVG application on preharvest drop of 'Marshall McIntosh' apples; 1998, Expt. 3.

\begin{tabular}{|c|c|c|c|c|c|c|c|c|c|c|c|c|c|c|c|c|c|}
\hline \multirow{2}{*}{$\begin{array}{l}\text { Treatment }{ }^{2} \\
\left(\mathrm{mg} \cdot \mathrm{L}^{-1}\right)\end{array}$} & \multirow{2}{*}{$\begin{array}{c}\text { Weeks before } \\
\text { anticipated } \\
\text { harvest }\end{array}$} & \multirow{2}{*}{$\begin{array}{c}\text { Date } \\
\text { applied }\end{array}$} & \multicolumn{15}{|c|}{ Cumulative drop (\%) } \\
\hline & & & 4 Sept. & 8 Sept. & 10 Sept. 1 & 14 Sept. 1 & 17 Sept. 2 & 21 Sept. 2 & 24 Sept. 2 & 28 Sept. & 1 Oct. & 5 Oct. & 8 Oct. & 13 Oct. & 15 Oct. & 19 Oct. & 22 Oct. \\
\hline Control & --- & --- & 2.4 & 8 & 11 & 21 & 33 & 54 & 64 & 83 & 96 & 98 & 99 & 99 & 100 & 100 & 100 \\
\hline AVG 90 & 6 & 3 Aug. & 0.4 & 2 & 3 & 5 & 8 & 14 & 17 & 28 & 47 & 60 & 71 & 79 & 83 & 90 & 92 \\
\hline AVG 90 & 5 & 10 Aug. & 0.3 & 2 & 2 & 4 & 7 & 12 & 16 & 28 & 45 & 56 & 64 & 72 & 76 & 85 & 88 \\
\hline AVG 90 & 4 & 18 Aug. & 0.2 & 3 & 3 & 5 & 8 & 11 & 16 & 24 & 37 & 50 & 60 & 67 & 70 & 81 & 83 \\
\hline AVG 90 & 3 & 24 Aug. & 0.6 & 3 & 4 & 6 & 8 & 14 & 20 & 29 & 44 & 54 & 63 & 71 & 74 & 84 & 87 \\
\hline AVG 90 & 2 & 31Aug. & 1.3 & 7 & 8 & 11 & 13 & 16 & 17 & 21 & 31 & 34 & 45 & 49 & 52 & 57 & 61 \\
\hline \multicolumn{18}{|l|}{ Significance } \\
\hline \multicolumn{3}{|l|}{ AVG } & $* *$ & $* * *$ & $* * *$ & $* * *$ & $* * *$ & $* * *$ & $* * *$ & $* * *$ & $* * *$ & $* * *$ & $* * *$ & $* * *$ & $* * *$ & $* * *$ & $* * *$ \\
\hline \multicolumn{3}{|c|}{ Time of application } & NS & $\mathrm{L}^{* * *}$ & $\mathrm{~L}^{*}$ & NS & NS & NS & NS & NS & $\mathrm{L}^{*}$ & $\mathrm{~L}^{* *}$ & $\mathrm{~L}^{* * * *}$ & $\mathrm{~L}^{* * *}$ & $\mathrm{~L}^{* * * *}$ & $\mathrm{~L}^{* * * *}$ & $\mathrm{~L}^{* * * *}$ \\
\hline \multicolumn{3}{|c|}{$\mathrm{AVG} \times$ drop date } & NS & $* *$ & $*$ & NS & NS & NS & NS & NS & $*$ & $* *$ & $* * *$ & $* * *$ & $* * *$ & $* * *$ & $* * *$ \\
\hline
\end{tabular}

${ }^{\mathrm{z}} \mathrm{AVG}$ was applied as the Retain formulation at the TRV of $1169 \mathrm{~L} \cdot \mathrm{ha}^{-1}$ with $0.1 \%$ Silwet.

NS,*******Nonsignificant at or significant at $P=0.05,0.01$, or 0.001 , respectively; $\mathrm{L}=$ linear and $\mathrm{Q}=$ quadratic response.

Table 6. Effect of time of AVG application on fruit weight, fruit quality parameters, and ripening of 'Marshall McIntosh' apples; 1998, Expt. 3. Mean of harvests on 10 Sept., 17 Sept., 24 Sept., and 1 Oct.

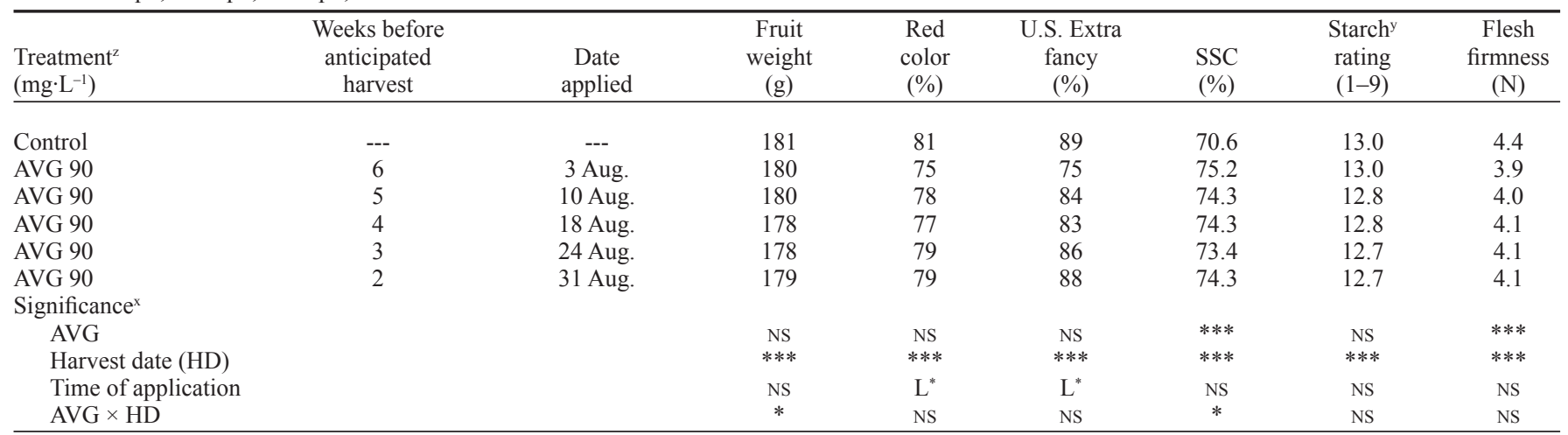

${ }^{\mathrm{z}} \mathrm{AVG}$ was applied as the Retain formulation at the TRV of $1169 \mathrm{~L} \cdot \mathrm{ha}^{-1}$ with $0.1 \%$ Silwet.

y $1-3=$ immature; $4-6=$ mature; and 7-9 = over-mature.

NS,,$* * * * * *$ Nonsignificant at or significant at $P=0.05,0.01$, or 0.001 , respectively; $\mathrm{L}=$ linear and $\mathrm{Q}=$ quadratic response. 
it advanced ripening compared with AVG. This is in agreement with recent reports where NAA and AVG have been compared directly (Byers, 1997a; Greene et al., 1987; Greene and Schupp, 2004).

\section{Literature Cited}

Bangerth, F. 1978. The effect of a substituted amino acid on ethylene biosynthesis, respiration, ripening, and preharvest drop of apple fruit. J. Amer. Soc. Hort. Sci. 103:401-404.

Boller, W.J., R.C. Herner, and H. Kende. 1979. Assay for the enzymatic formation of an ethylene precursor 1-aminocyclopropane-1-carboxylic acid. Planta 145:293-303.

Blanpied, G.D., and K. J. Silsby. 1992. Predicting harvest date windows for apples. Cornell Coop. Ext. Info. Bul. 221.

Byers, R.E. 1997a. Effects of aminoethoxyvinylglycine (AVG) on preharvst drop and maturity of 'Delicious' apples. J. Tree Fruit Prod. 2:53-75.
Byers, R.E. 1997b. Effects of aminoethoxyvinylglycine (AVG) on preharvest fruit drop, maturity, and cracking of several apple cultivars. J. Tree Fruit Prod. 2:77-97.

Clarke, G.G. W.E. Shafer, and B.N. Devisetty. 1996 ABG-3168: A new naturally-occurring plant growth regulator for the apple industry. Proc. Mass. Fruit Growers' Assn. 102:85-89.

Greene,D.W.2000. Development of aminoethoxyvinylglycine (AVG) to retard preharvest drop in apples. Acta Hort. 527:105-109.

Greene, D.W. 2002a. Development of new plant growth regulators from a university perspective. HortTechnology 12:71-74.

Greene, D.W. 2002b. Preharvest drop control and maturity of 'Delicious' apples as affected by aminoethoxyvinylglycine (AVG). J. Tree Fruit Prod. 3:1-10.

Greene, D.W., K. Kaminsky, and J. Sincuk. 1987. An evaluation of stop drop materials in 1986. Proc. Mass. Fruit Growers' Assn. 93:74-78.

Greene, D.W. and J.R. Schupp. 2004. Effect of aminoethoxyvinylglycine (AVG) on preharvest drop, fruit quality, and maturation of 'McIntosh' apples. II. Effect of timing and concentration relationships and spray volume. HortScience 39:1036-1041.

Schupp, J.R. and D.W. Greene. 2004. Effect of aminoethoxyvinylglycine (AVB) on preharvest drop, fruit quality, and maturation of 'McIntosh' apples: I. Concentration and timing of dilute applications of AVG. HortScience 39:1030-1035.

Shafer, W.E., R. Fritts, and B.N. Devisetty. 1995. A commercial formulation of AVG for use on apples. Proc. Wash State Hort. Meeting 91:169-171.

Stover, E., M.J. Fargione, C.B. Watkins, and K.A. Iungerman. 2003. Harvest management of 'Marshall McIntosh' apples: Effects of AVG, NAA, ethephon, and summer pruning on preharvest drop and fruit quality. HortScience 38:1093-1099.

Wargo, J.M., I.A. Merwin, and C.B. Watkins. 2004. Nitrogen fertilization, midsummer trunk girdling, and AVG treatment affect maturity and quality of 'Jonagold' apples. HortScience 39:493-500. 